\title{
A knife which was embedded into the thoracic cavity: an interesting case
}

\section{Torasik kaviteye gömülü bıçak: ilginç bir olgu}

\author{
Yücel AKKAŞ ${ }^{1 a}$, Neslihan Gülay PERi', Aysu Hayriye TEZCAN², Bülent KOÇER', Tevfik KAPLAN³ ${ }^{3}$ Rasih YAZKAN \\ ${ }^{1}$ Ankara Numune Research and Training Hospital, Department of Thoracic Surgery, Ankara, \\ ${ }^{2}$ Ankara Numune Research and Training Hospital, Department of Anesthesiology, Ankara, \\ ${ }^{3}$ Ufuk University Faculty of Medicine, Department of Thoracic Surgery, Ankara, \\ ${ }^{4}$ Süleyman Demirel University School of Medicine, Department of Thoracic Surgery, Isparta, TURKEY
}

\begin{abstract}
In this case report we present an alternative intubation method and treatment of a patient who had admitted to the emergency department with a stab wound in his thorax. A 75-year-old man was brought to the emergency department with a knife in the posterior side of the thorax. After the anteroposterior lung $x$-ray was obtained, endotracheal intubation was done with a single-lumen tube in the right lateral decubitus position and the knife which was penetrated to the thorax was pulled out via a thoracotomy. We suggest that such foreign bodies should be withdrawn out with a controlled manner via sternotomy or thoracotomy.
\end{abstract}

Key Words: Penetrating wound, thoracic wall, thoracic surgical procedures, intubation

\section{öz}

Bu olgu sunumunda delici kesici alet yaralanması nedeniyle acil servise başvuran hastaya uygulanan farklı entübasyon ve tedavi yönetimi anlatılmaktadır. Yetmiş beş yaşında bir erkek hasta sırtına saplı bir bıçakla acil servise getirildi. Hastaya anteroposterior akciğer grafisi çekildikten sonra sağ lateral dekübit pozisyonunda tek lümenli tüple endotrakeal entübasyon yapıldıktan sonra torakotomi yapılarak toraksa invaze olan bıçak çıkartıldı. Bu tip yabancı cisimlerin sternotomi veya torakotomi yardımı ile kontrollü olarak çıkartılmasını önermekteyiz.

Anahtar Kelimeler: Penetran yaralanma, göğüs duvarı, torasik cerrahi yöntem, entübasyon

Corresponding Authora: Dr. Yücel AKKAŞ. Ankara Numune Research and Training Hospital, Department of Thoracic Surgery, Ankara, TURKEY Phone: +90 5054381295 e-mail: y.akkas@yahoo.com

Received 09.11.2015, accepted 08.12.2015

doi: $10.18663 /$ tjcl.09008

This article was presented as a poster at TUSAD 36. National Congress, 15-19 October 2014, in Çeşme-TURKEY 


\section{Introduction}

Penetrating traumas make up $20-30 \%$ of the thoracic injuries. Isolated penetrating thorax traumas usually occur with firearms or with stabbing [1]. Here we present a case who had admitted to the emergency department with a stab wound in his chest. The alternative intubation method and treatment of this interesting case was presented.

\section{Case Report}

A 75 year old male patient had admitted to the emergency department with the knife on his back. He was lying on a face down position from the moment he was being stabbed on his back. On physical examination a bread knife, penetrating the thoracic cavity from the 8 th intercostal space, $2 \mathrm{~cm}$ lateral to left paravertebral line was detected (Fig. 1).

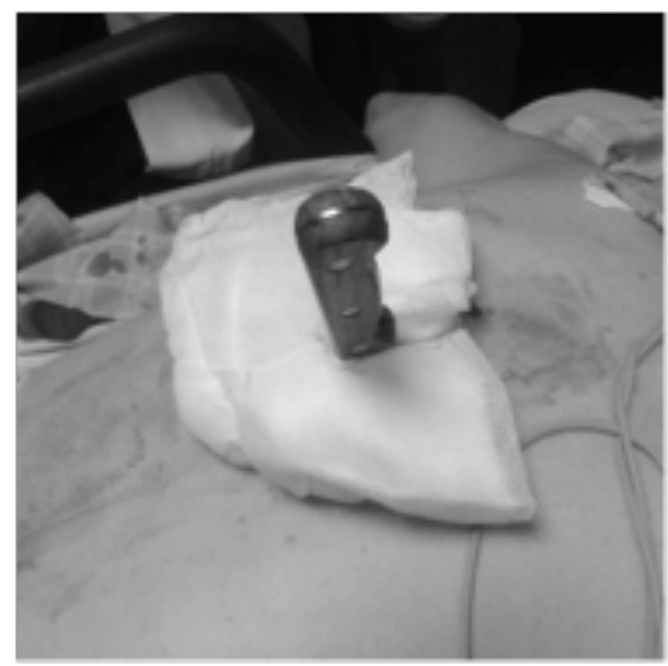

Figure 1. The image of the patient who was admitted to the emergency unit with a knife on his back.

The knife was moving simultaneously with the cardiac beats as seen on the monitor. The respiratory sounds were normal on auscultation. His hemoglobin level was $11.7 \mathrm{~g} / \mathrm{dl}$. An anteroposterior chest $\mathrm{x}$-ray was taken on lying position and there was no apparent hemopneumothorax. The radio-opaque knife was visible at the cardiac shadow of the mediastinum (Fig. 2).

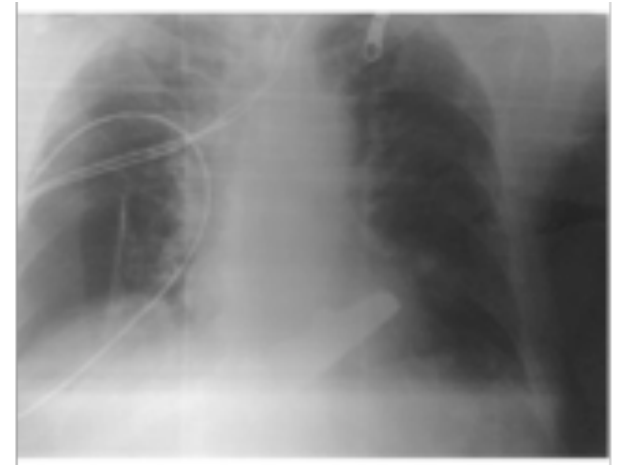

Figure 2. The radio-opaque image of the knife in the mediastinum in the anteroposterior chest $\mathrm{x}$-ray.
With the suspicion of an intra-thoracic organ injury, an urgent thoracotomy was planned. As prone position couldn't be given the patient was intubated on the right lateral decubitus position. Left lateral thoracotomy was performed. Dense adhesions between pleural surfaces was separated. The knife was observed to penetrate and transect the superior segment of the lower lobe of the lung which was $3 \mathrm{~cm}$ lateral to the location of the entry (Fig. 3).

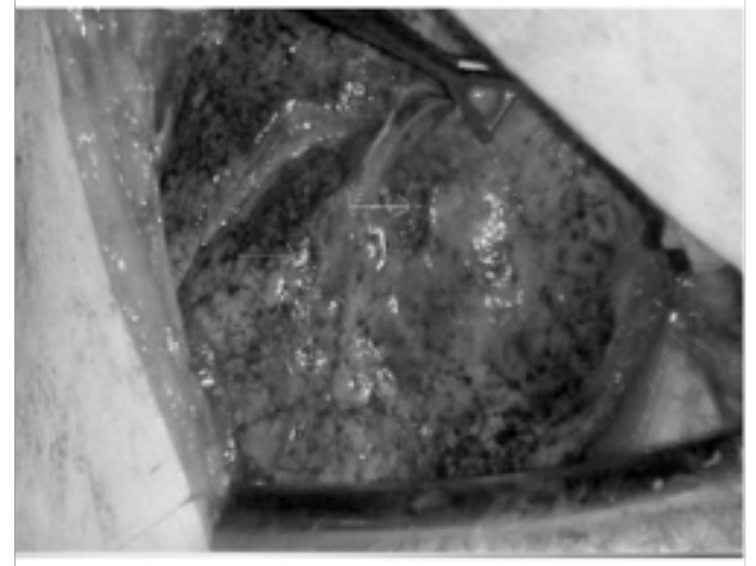

Figure 3. The image of the entry and exit wound of the knife in the superior segment of the lower lobe of the lung.

It was concluded that, the adhesions prevented pneumothorax formation. Fortunately no other intra-thoracic organ damage was detected. The knife was taken out of the thorax in a controlled manner. The parenchymal injury was repaired. The patient was discharged on the 6th postoperative day uneventfully (Fig. 4).

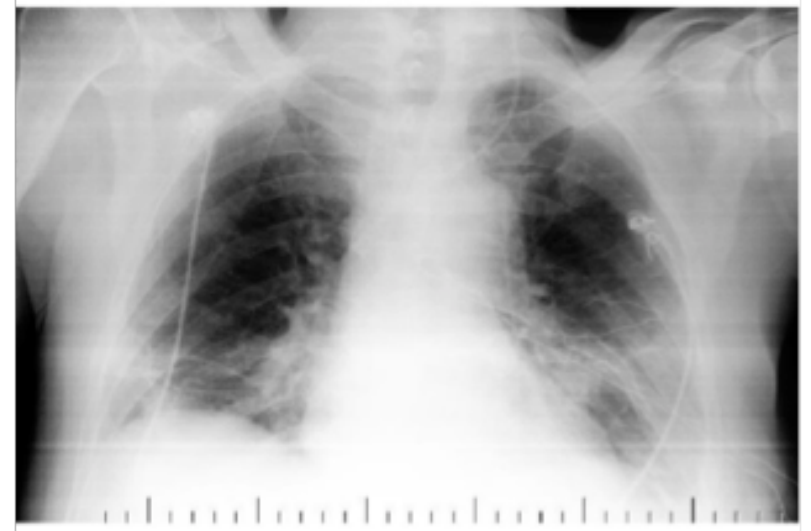

Figure 4. The image of the post-operative postero-anterior chest x-ray.

\section{Discussion}

The mortality due to penetrating thorax traumas were between $15-77 \%$ depending on the severity of the trauma, number of damaged organs and presence of a great vessel injury. It is seen in males more frequently. Vital organs such as the 
heart, lungs, major vessels and diaphragm may be damaged during penetrating thorax traumas, causing morbidity and mortality due to perfusion and oxygenation dysfunction in the body. A multidisciplinary approach, early diagnosis and urgent surgical intervention may yield successful results $[2,3]$.

Emergency radiological imaging are of vital importance in penetrating traumas [3]. We did not have the opportunity to perform a posterioanterior chest x-ray and computerized tomography due to the location of entry of the knife in our patient, which is why we could only evaluate the patient with an anteroposterior chest x-ray.

The fact that the knife was visible in the mediastinal area, lack of hemopneumothorax and the movements of the knife along with the cardiac rhythm first made us think of a cardiac injury. Therefore, we decided that it would be appropriate to take out the knife under direct vision not to cause any major hemorrhage due to suspicion of cardiac and big vessel injury, which was compliant with the literature $[3,4]$.

As intubation in the supine position was not possible due to the occurrence of the event, the patient was intubated in the right lateral decubitus position. Zebele et al [3] also performed an intubation in the lateral decubitus position when taking out a pair of secateurs in the thoracic wall.
As a conclusion if a suspicion of cardiac or great vessel injury arises, the foreign body should be taken out by direct vision by a sternotomy or a thoracotomy. During the diagnostic period extreme caution must be taken in order not to change the position of the foreign object.

\section{Declaration of conflicting interests}

The authors declared no conflicts of interest with respect to the authorship and/or publication of this article.

\section{Funding}

The authors received no financial support for the research and/or authorship of this article.

\section{References}

1. Ceran S, Sunam GS, Arıbas OK, Gormus N, Solak H. Chest trauma in children. Eur J Cardiothorac Surg 2002; 21: 57-9.

2. Altunkaya A, Aktunc E, Kutluk AC, et al. Analysis of 282 patients with thoracic trauma. Turk J Thorac Cardiovasc Surg 2007; 15: 127-32.

3. Zebele C, Gianoli M, Elenbaas T, Brink P, Zundert AA. Unusual case of left chest wound. Asian Cardiovasc Thorac Ann 2011; 19: 349.

4. Laisaar T. Unusual case of self-inflicted thoracic knife wounds with five knives embedded in the left thoracic cavity. Eur J Cardiothorac Surg 2005; 28: 653-4. 